\title{
Role of redox-inactive metals in controlling the redox potential of heterometallic manganese-oxido clusters
}

\author{
Keisuke Saito ${ }^{1,2}$ (D) Minesato Nakagawa ${ }^{1} \cdot$ Manoj Mandal $^{2} \cdot$ Hiroshi Ishikita $^{1,2}(\mathbb{D}$
}

Received: 18 December 2020 / Accepted: 11 May 2021 / Published online: 28 May 2021

(c) The Author(s) 2021

\begin{abstract}
Photosystem II (PSII) contains $\mathrm{Ca}^{2+}$, which is essential to the oxygen-evolving activity of the catalytic $\mathrm{Mn}_{4} \mathrm{CaO}_{5}$ complex. Replacement of $\mathrm{Ca}^{2+}$ with other redox-inactive metals results in a loss/decrease of oxygen-evolving activity. To investigate the role of $\mathrm{Ca}^{2+}$ in this catalytic reaction, we investigate artificial $\mathrm{Mn}_{3}[\mathrm{M}] \mathrm{O}_{2}$ clusters redox-inactive metals $[\mathrm{M}]\left([\mathrm{M}]=\mathrm{Mg}^{2+}\right.$, $\mathrm{Ca}^{2+}, \mathrm{Zn}^{2+}, \mathrm{Sr}^{2+}$, and $\mathrm{Y}^{3+}$ ), which were synthesized by Tsui et al. (Nat Chem 5:293, 2013). The experimentally measured redox potentials $\left(E_{\mathrm{m}}\right)$ of these clusters are best described by the energy of their highest occupied molecular orbitals. Quantum chemical calculations showed that the valence of metals predominantly affects $E_{\mathrm{m}}\left(\mathrm{Mn}^{\mathrm{III} / \mathrm{IV}}\right)$, whereas the ionic radius of metals affects $E_{\mathrm{m}}\left(\mathrm{Mn}^{\mathrm{III} / \mathrm{IV}}\right)$ only slightly.
\end{abstract}

Keywords Water-splitting enzyme $\cdot$ Highest occupied molecular orbital $\cdot$ Density functional theory $\cdot$ Redox potential shift · Artificial Mn clusters $\cdot$ Oxygen-evolving center

\section{Introduction}

Plants, algae, and cyanobacteria use the water-splitting enzyme photosystem II (PSII) for oxygen evolution. The oxygen evolution proceeds at the oxygen-evolving center, the $\mathrm{Mn}_{4} \mathrm{CaO}_{5}$ cluster. The cluster consists of a distorted cubane [Mn1, Mn2, Mn3, four oxygen atoms, and $\left.\mathrm{Ca}^{2+}\right]$ and "dangling" Mn4 (Fig. 1) (Umena et al. 2011). The $\mathrm{Mn}_{4} \mathrm{CaO}_{5}$ cluster has two ligand water molecules, W1 and $\mathrm{W} 2$, at the Mn4 site and another two ligand water molecules, W3 and W4, at the $\mathrm{Ca}^{2+}$ site (Fig. 1). The catalytic cycle moves through a series of oxidation states, denoted as $\mathrm{S}_{n}\left(n=0,1,2\right.$, and 3). As electron transfer occurs, $\mathrm{S}_{n}$ increases. During the catalytic cycle, four electrons from two of the substrate water molecules are removed, and $\mathrm{O}_{2}$

Keisuke Saito

ksaito@appchem.t.u-tokyo.ac.jp

$\bowtie$ Hiroshi Ishikita

hiro@ appchem.t.u-tokyo.ac.jp

1 Department of Applied Chemistry, Graduate School of Engineering, The University of Tokyo, 7-3-1 Hongo, Bunkyo-ku, Tokyo 113-8654, Japan

2 Research Center for Advanced Science and Technology, The University of Tokyo, 4-6-1 Komaba, Meguro-ku, Tokyo 153-8904, Japan evolves in the $S_{3}$ to $S_{0}$ transition (Shen 2015; Cardona and Rutherford 2019).

In the $\mathrm{Mn}_{4} \mathrm{CaO}_{5}$ cluster, a redox-inactive $\mathrm{Ca}^{2+}$ is essential for the oxygen evolution activity, as oxygen is not evolved when $\mathrm{Ca}^{2+}$ is removed (Ono and Inoue 1988) or replaced with $\mathrm{Dy}^{3+}, \mathrm{Cu}^{2+}, \mathrm{Cd}^{2+}$ (Lee et al. 2007), $\mathrm{K}^{+}, \mathrm{Rb}^{+}$, and $\mathrm{Cs}^{+}$ (Ono et al. 2001). The $\mathrm{Mn}_{4} \mathrm{SrO}_{5}$ cluster can evolve oxygen but the activity is lower than that of the native $\mathrm{Mn}_{4} \mathrm{CaO}_{5}$ cluster (Yachandra and Yano 2011). Koua et al. identified that the distance between $\mathrm{Sr}^{2+}$ and W3 (2.6 $\AA$ ) was longer than that between $\mathrm{Ca}^{2+}$ and W3 (2.4 $\AA$ ) (Koua et al. 2013) and proposed that the long $\mathrm{Sr}^{2+\ldots} \mathrm{W} 3$ distance contributed to the decrease in the activity upon replacement of $\mathrm{Ca}^{2+}$ with $\mathrm{Sr}^{2+}$.

It was speculated that $\mathrm{Ca}^{2+}$ might be responsible for the distorted cubane structure of the $\mathrm{Mn}_{4} \mathrm{CaO}_{5}$ cluster (Kawakami et al. 2011). However, the removal of $\mathrm{Ca}^{2+}$ does not alter the $\mathrm{Mn}_{3} \mathrm{CaO}_{4}$ cubane structure (Saito and Ishikita 2014; Siegbahn 2014, 2017), as suggested by the extended X-ray absorption fine structure (EXAFS) and the electron paramagnetic resonance (EPR) measurements (Latimer et al. 1998; Yachandra and Yano 2011; Lohmiller et al. 2012). Note that the Jahn-Teller distortion for Mn(III) ions can be affected by $\mathrm{Ca}^{2+}$ (Yamaguchi et al. 2013). When $\mathrm{Ca}^{2+}$ is removed, the rearrangement of water molecules in the hydrogen-bond (H-bond) network of the redox-active 


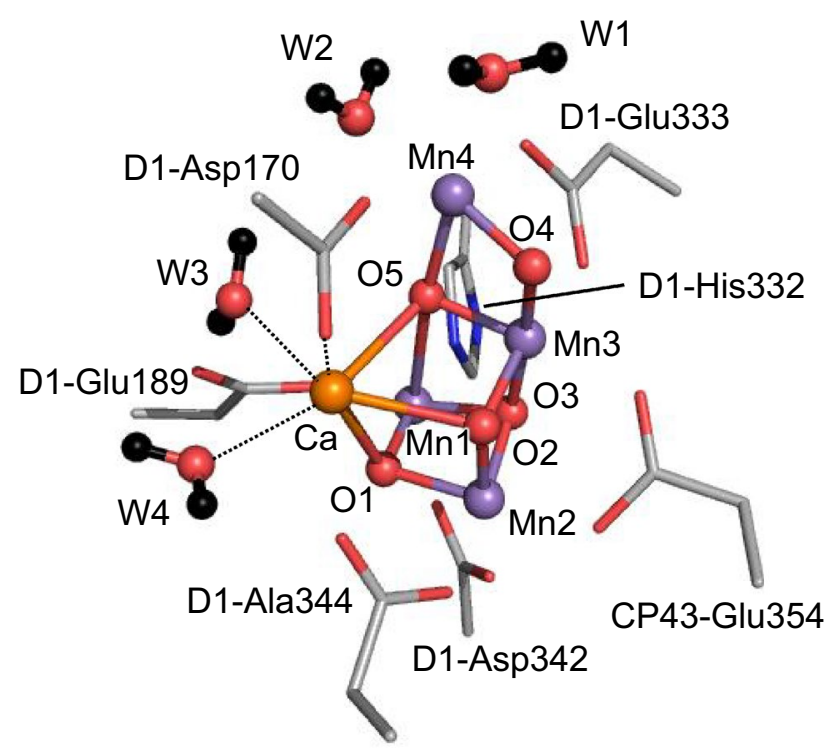

Fig. 1 Structure of the $\mathrm{Mn}_{4} \mathrm{CaO}_{5}$ cluster of PSII. Dotted lines indicate ligations to $\mathrm{Ca}^{2+}$

tyrosine (TyrZ) is observed (Saito and Ishikita 2014; Saito et al. 2020a). TyrZ is involved in electron transfer from the $\mathrm{Mn}_{4} \mathrm{CaO}_{5}$ cluster to the reaction center chlorophyll $\mathrm{P}_{\mathrm{D} 1}$. The rearrangement of the H-bond network increases its redox potential $\left(E_{\mathrm{m}}(\mathrm{TyrZ})\right)$ by $\sim 300 \mathrm{mV}$ and inhibits the formation of the downhill electron transfer pathway from the $\mathrm{Mn}_{4} \mathrm{CaO}_{5}$ cluster via TyrZ to $\mathrm{P}_{\mathrm{D} 1}$ (Saito et al. 2020a). Thus, $\mathrm{Ca}^{2+}$ is essential in both maintaining the H-bond network and optimizing electron transfer. The role of $\mathrm{Ca}^{2+}$ as the water binding site can be substituted with $\mathrm{H}_{3} \mathrm{O}^{+}$: recent theoretical studies showed that the $\mathrm{H}$-bond network, including the low-barrier H-bond between TyrZ and D1-His190, remains unaltered upon the replacement of $\mathrm{Ca}^{2+}$ with $\mathrm{H}_{3} \mathrm{O}^{+}$(Saito et al. 2020a).

$\mathrm{Ca}^{2+}$ is a prerequisite for the low-barrier $\mathrm{H}$-bond between W1 and D1-Asp61: they form a low-barrier H-bond in native PSII (Kawashima et al. 2018b; Saito et al. 2020a), whereas they cannot form in the absence of $\mathrm{Ca}^{2+}$ (Saito et al. 2020a). That is, $\mathrm{Ca}^{2+}$ decreases $\mathrm{p} K_{\mathrm{a}}(\mathrm{W} 1)$ electrostatically to a level of $\mathrm{p} K_{\mathrm{a}}(\mathrm{D} 1-\mathrm{Asp} 61)$ in native PSII, thus forming the lowbarrier $\mathrm{H}$-bond and facilitating proton transfer from $\mathrm{W} 1$ to D1-Asp61.

So far, the role of the $\mathrm{Ca}^{2+}$ can be summarized as follows: (i) maintaining the TyrZ H-bond network (Saito et al. 2011, 2020a; Kawashima et al. 2018a), including the lowbarrier H-bond between TyrZ and D1-His190 (Kawashima et al. 2018b; Saito et al. 2020a); (ii) optimizing $E_{\mathrm{m}}$ (TyrZ) in the electron transfer cascade (Saito et al. 2020a); and (iii) electrostatically decreasing $\mathrm{p} K_{\mathrm{a}}(\mathrm{W} 1)$ and facilitating proton transfer via the low-barrier H-bond with D1-Asp61 (Saito et al. 2020a).
Althogh it was proposed that $\mathrm{Ca}^{2+}$ might electrostatically affect the properties of the cluster (e.g., $\mathrm{p} K_{\mathrm{a}}$ and $E_{\mathrm{m}}$ ) (McEvoy and Brudvig 2006), the replacements of $\mathrm{Ca}^{2+}$ with $\mathrm{H}_{2} \mathrm{O}$ and $\mathrm{H}_{3} \mathrm{O}^{+}$lead to different $E_{\mathrm{m}}\left(\mathrm{Mn}^{\text {III/IV }}\right)$ values due to different H-bond patterns in PSII (Saito et al. 2020a). Artificial Mn clusters with redox-inactive metals (Zhang et al. 2015; Mukherjee et al. 2012; Tsui et al. 2013; Kanady et al. 2013; Tsui and Agapie 2013; Lin et al. 2015) may serve as reference model systems since the corresponding H-bond network is absent. Tsui et al. synthesized artificial $\mathrm{Mn}_{3}[\mathrm{M}]$ $\mathrm{O}_{2}$ and clusters with redox-inactive metals $[\mathrm{M}]\left([\mathrm{M}]=\mathrm{Mg}^{+}\right.$, $\mathrm{Ca}^{2+}, \mathrm{Zn}^{2+}, \mathrm{Sr}^{2+}$, and $\left.\mathrm{Y}^{3+}\right)$ (Fig. 2), showing that $E_{\mathrm{m}}\left(\mathrm{Mn}^{\mathrm{III}} /\right.$ ${ }^{\mathrm{IV}}$ ) depends on the Lewis acidity of [M] (i.e., the $\mathrm{p} K_{\mathrm{a}}$ of aqua complexes of [M]) (Tsui et al. 2013). A similar correlation between the ligand-to-metal charge transfer energy (related to $E_{\mathrm{m}}$ ) and the Lewis acidity has also been reported in the $\mathrm{Fe}$ and Mn complexes (Bang et al. 2014; Krewald et al. 2016).

$E_{\mathrm{m}}$ can be calculated as the free energy difference between the oxidized and reduced states, including the entropic effect of the solvent (Marenich et al. 2014; Pitari et al. 2015; Amin et al. 2013; Krewald et al. 2016). $E_{\mathrm{m}}$ also correlates with the ionization potential as shown for various complexes, including Mn complexes (Marenich et al. 2014; Krewald et al. 2016). The ionization potential can be regarded as the free energy difference between the oxidized and the reduced states when the reorganization effect upon the redox reaction (including the electronic relaxation, the solvent reorganization, and the structural change of the molecule) is neglective. As the ionization potential (or the electronic affinity) is correlated with the energy levels of the lowest unoccupied molecular orbital (LUMO) and the highest occupied molecular orbital (HOMO) in density functional theory (DFT) (Kohn-Sham orbital) (Zhang and Musgrave 2007), $E_{\mathrm{m}}$ should be calculated based on the HOMO or LUMO energy calculated using DFT. An electron releases from the HOMO upon oxidation, whereas an electron enters the LUMO upon reduction. Thus, the HOMO energy corresponds to the potential for one-electron oxidation, and the LUMO energy corresponds to the potential for one-electron reduction. When the redox reaction is reversible, the midpoint potential $E_{\mathrm{m}}$ is located at the midpoint between the oxidation and reduction potentials, i.e., $E_{\mathrm{m}}$ and the two potentials have the same tendency. Indeed, the $E_{\mathrm{m}}$ of quinones can be determined based on the LUMO energy (Ishikita and Saito 2020) as accurately as the free energy difference (Kishi et al. 2017). For complexes that include transition metals, high correlations between the HOMO and/ or LUMO energy and the experimentally measured $E_{\mathrm{m}}$ value were observed [e.g., organic compounds (Mendez-Hernandez et al. 2013), $\beta$-diketones complexes, including $\mathrm{Mn}$ and $\mathrm{Fe}$ (Conradie 2015), and FeCo proteins (Dance 2006)]. For the natural $\mathrm{Mn}_{4} \mathrm{CaO}_{5}$ cluster in the PSII protein environment, $E_{\mathrm{m}}$ can be determined based on the HOMO energy 
(a)

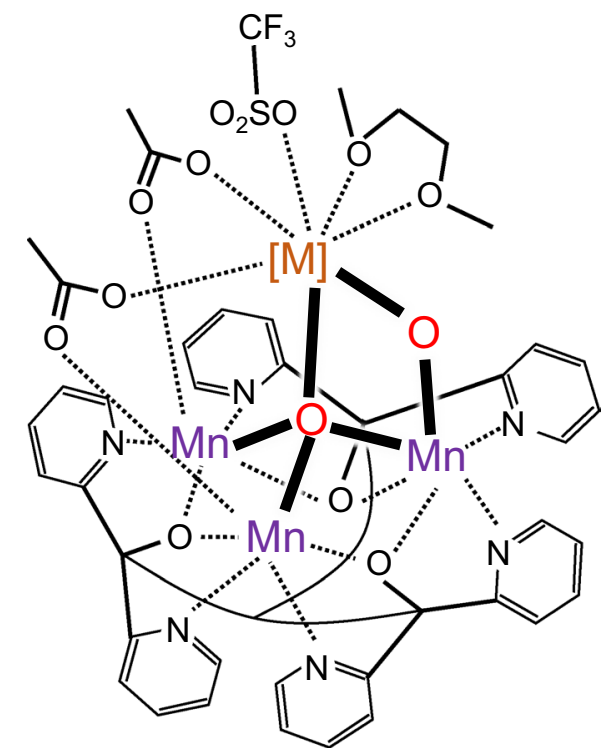

(b)

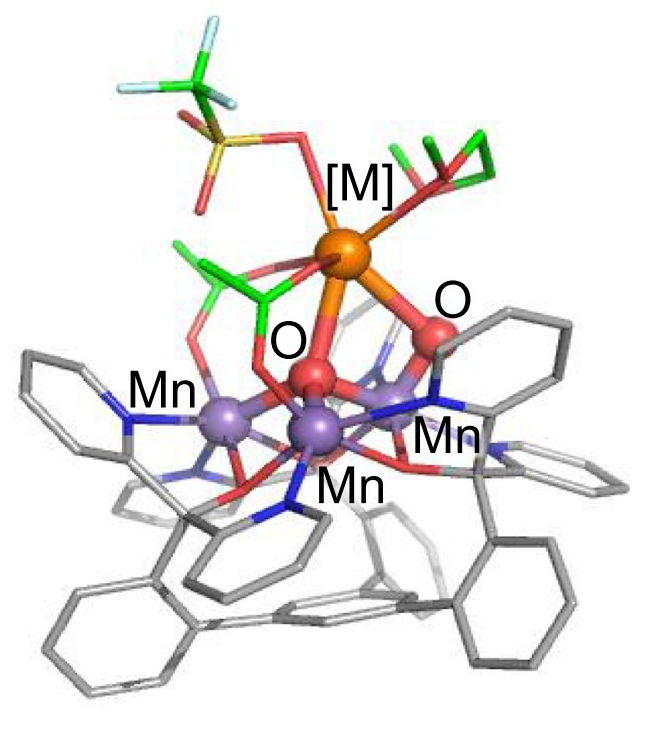

Fig. 2 Structure of the $\mathrm{Mn}_{3}[\mathrm{M}] \mathrm{O}_{2}$ cluster for $[\mathrm{M}]=\mathrm{Ca}^{2+}, \mathrm{Sr}^{2+}$, and $\mathrm{Y}^{3+}$ (Tsui et al. 2013) a Chemical structure. b Three-dimensional structure. For the detail of ligands, see Table S1

(Mandal et al. 2020; Saito et al. 2020a, b). Here we calculate the $E_{\mathrm{m}}$ values of the artificial clusters (Tsui et al. 2013; Tsui and Agapie 2013) based on the HOMO energy and explain how the redox-inactive metal affects $E_{\mathrm{m}}\left(\mathrm{Mn}^{\mathrm{III/IV}}\right)$.

\section{Computational details}

The crystal structures of synthetic $\mathrm{Mn}_{3}[\mathrm{M}] \mathrm{O}_{2}$ clusters $\left([\mathrm{M}]=\mathrm{Na}^{+}, \mathrm{Sr}^{2+}, \mathrm{Ca}^{2+}, \mathrm{Zn}^{2+}\right.$, and $\mathrm{Y}^{3+}$ ) (Tsui et al. 2013) and $\mathrm{Mn}_{3}[\mathrm{M}] \mathrm{O}_{4}$ clusters $\left([\mathrm{M}]=\mathrm{Sr}^{2+}, \mathrm{Ca}^{2+}, \mathrm{Zn}^{2+}, \mathrm{Mn}^{3+}\right.$, $\mathrm{Sc}^{3+}$ and $\mathrm{Y}^{3+}$ ) (Tsui and Agapie 2013) were used as the basis for geometry optimization using unrestricted DFT (UDFT), with the B3LYP functional and LACVP* basis set (for optimized structures, see Supporting Information). For efficiency, the cluster was considered to comprise ferromagnetically coupled Mn atoms, (Tsui et al. 2013) where the total spin, $S$, was $12 / 2$ for the $\mathrm{Mn}_{3}[\mathrm{M}] \mathrm{O}_{2}$ cluster and $10 / 2$ for the $\mathrm{Mn}_{3}[\mathrm{M}] \mathrm{O}_{4}$ cluster. We note that, in the calculation of the native $\mathrm{Mn}_{4} \mathrm{CaO}_{5}$ of PSII, the difference in $S$ (e.g., $S=1 / 2$ in $S_{2}$ (Zimmermann and Rutherford 1986), high, low, ferromagnetic, and antiferromagnetic) did not affect the (i) resulting geometry (Ames et al. 2011; Isobe et al. 2012), (ii) potential energy profile of proton transfer (Kawashima et al. 2018b), (iii) redox potential of each Mn site (Mandal et al. 2020), or (iv) $\mathrm{p} K_{\mathrm{a}}$ values of ligand water molecules W1-W4 (Saito et al. 2020c). The resulting oxidation states for three $\mathrm{Mn}$ atoms were $\mathrm{Mn}(\mathrm{III})_{3}$ and $\mathrm{Mn}(\mathrm{IV}) \mathrm{Mn}(\mathrm{III})_{2}$ for the $\mathrm{Mn}_{3}[\mathrm{M}] \mathrm{O}_{2}$ and the $\mathrm{Mn}_{3}[\mathrm{M}] \mathrm{O}_{4}$ clusters, respectively (for atomic spin density, see Table S2). $E_{\mathrm{m}}\left(\mathrm{Mn} 1^{\mathrm{III} / \mathrm{VV}}\right.$ ) was calculated from the HOMO energies, since the value of $E_{\mathrm{m}}$ for one-electron oxidation is correlated with the energy of the highest occupied molecular orbital (HOMO) (MendezHernandez et al. 2013; Igarashi and Seefeldt 2003; Mandal et al. 2020). Using the optimized geometries in vacuum, the HOMO energy $\left(E_{\mathrm{HOMO}}\right)$ was calculated in dichloromethane $\left(\mathrm{CH}_{2} \mathrm{Cl}_{2}\right.$, dielectric constant 8.93) using the polarizable continuum model (PCM). All calculations were performed with Jaguar program [Schrödinger, LLC, 2012, New York]. The initial-guess wavefunctions were obtained using the ligand field theory (Vacek et al. 1999) implemented in the Jaguar program.

\section{Results and discussion}

The calculated $E_{\mathrm{HOMO}}$ values for the artificial $\mathrm{Mn}_{3}[\mathrm{M}] \mathrm{O}_{2}$ clusters ([M] $=\mathrm{Na}^{+}, \mathrm{Sr}^{2+}, \mathrm{Ca}^{2+}, \mathrm{Zn}^{2+}$, and $\mathrm{Y}^{3+}$ ) show a correlation with the experimentally measured $E_{\mathrm{m}}\left(\mathrm{Mn}^{\mathrm{III} / \mathrm{IV}}\right)$ values (Fig. 3) in $\mathrm{CH}_{2} \mathrm{Cl}_{2}$ and are best fitted to Eq. (1).

$E_{\mathrm{m}}\left(\mathrm{V}\right.$ vs. $\left.\mathrm{Fc} / \mathrm{Fc}^{+}\right)=-0.302 E_{\text {HOMO }}(\mathrm{eV})-1.710$,

where $\mathrm{Fc} / \mathrm{Fc}+$ denotes ferrocene electrode. A similar correlation is also observed in the $\mathrm{Mn}_{3}\left[\mathrm{M}^{-} \mathrm{O}_{4}\right.$ cubane clusters $\left([\mathrm{M}]=\mathrm{Sr}^{2+}, \mathrm{Ca}^{2+}, \mathrm{Zn}^{2+}, \mathrm{Mn}^{3+}, \mathrm{Sc}^{3+}\right.$, and $\mathrm{Y}^{3+}$ ) (Tsui and Agapie 2013) (Fig. S1). The coefficient of -0.302 in Eq. (1) is the conversion factor from MO energy to $E_{\mathrm{m}}$, which may be associated with the solvation effect (Schmidt am Busch and Knapp 2005), whereas the offset of $-1.710 \mathrm{~V}$ is 
Fig. 3 Experimentally measured $E_{\mathrm{m}}\left(\mathrm{Mn}^{\text {III/IV }}\right)$ values in $\mathrm{CH}_{2} \mathrm{Cl}_{2}$

(Tsui and Agapie 2013) and

calculated HOMO energy levels

$\left(E_{\mathrm{HOMO}}\right)$ of the $\mathrm{Mn}_{3}[\mathrm{M}] \mathrm{O}_{2}$

clusters. The coefficient of deter-

mination $\left(R^{2}\right)$ is 0.96

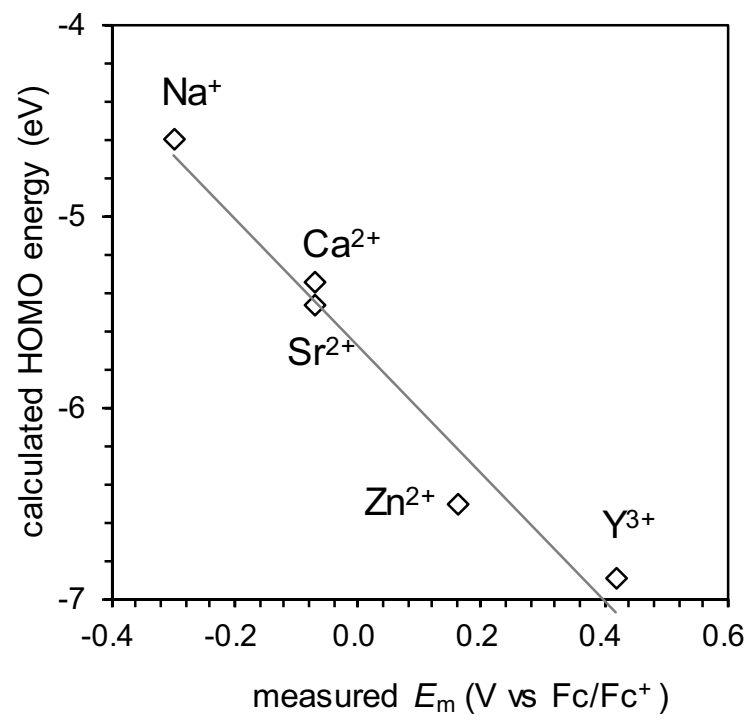

$\mathrm{Mn}_{3}[\mathrm{M}] \mathrm{O}_{2}$

associated with a difference between the absolute electrode potential and the $\mathrm{Fc} / \mathrm{Fc}^{+}$electrode potential and liquid junction potential (Kishi et al. 2017). These factors depend on the size and the net charge of the QM system, the solvent, and the reference electrode (e.g., see the caption of Fig. S1). Thus, Eq. (1) is applicable only to similar molecular groups (e.g., artificial $\mathrm{Mn}_{3}[\mathrm{M}] \mathrm{O}_{2}$ clusters).

Using Eq. (1), $E_{\mathrm{HOMO}}$ can be converted to $E_{\mathrm{m}}$. The calculated $E_{\mathrm{m}}$ values correlate with the experimentally measured $E_{\mathrm{m}}$ values (Fig. 4, blue diamonds). In the $\mathrm{Mn}_{3}[\mathrm{M}] \mathrm{O}_{2}$ clusters synthesized by Tsui, each $[\mathrm{M}]$ has different ligand groups (Table $\mathrm{S} 1$ ). Accordingly, the absolute $E_{\mathrm{m}}$ values are affected by $[\mathrm{M}]$ and the ligand groups. To evaluate the direct influence of electrostatic and the van der Waals interactions with $[\mathrm{M}]$ on the $E_{\mathrm{m}}$ of the $\mathrm{Mn}_{3}[\mathrm{M}] \mathrm{O}_{2}$ cluster, the metal $[\mathrm{M}]$ was removed from the geometry-optimized $\mathrm{Mn}_{3}[\mathrm{M}] \mathrm{O}_{2}$ cluster. The calculated $E_{\mathrm{m}}$ values for the metal-removed clusters do not correlate with the experimentally measured $E_{\mathrm{m}}$ values (Fig. 4, red circles).

The removal of $\mathrm{Y}^{3+}$ resulted in an increase of $1.5 \mathrm{~V}$ in $E_{\mathrm{m}}$, whereas the removal of $\mathrm{Na}^{+}$resulted in an increase of $0.5 \mathrm{~V}$ in $E_{\mathrm{m}}$ (Fig. 5a). These results suggest that the valence of $[\mathrm{M}]$ is the main factor determining $E_{\mathrm{m}}$. In addition, the removal of a metal with a large radius (e.g., $\mathrm{Sr}^{2+}$ ) resulted in a large increase in $E_{\mathrm{m}}$, whereas the removal of a metal with a small radius (e.g., $\mathrm{Zn}^{2+}$ ) resulted in a small increase in $E_{\mathrm{m}}$ (Fig. 5b). For metals with the same valence (e.g., $\mathrm{Sr}^{2+}$, $\mathrm{Ca}^{2+}$, and $\mathrm{Zn}^{2+}$ ), the difference in $E_{\mathrm{m}}$ can be explained by the difference in the ionic radius of the redox-inactive metal $[\mathrm{M}]$. As the radius of $[\mathrm{M}]$ increases, the distance between $[\mathrm{M}]^{2+}$ and $\mathrm{Mn}$ increases, leading to weak electrostatic interactions between $\mathrm{Mn}$ and $[\mathrm{M}]^{2+}$. Thus, of the $[\mathrm{M}]^{2+}$ metals, [M] with large radii have a smaller influence on $E_{\mathrm{m}}$. The effect that the ionic radius has on the difference in $E_{\mathrm{m}}$ can be explained in terms of the Lewis acidity of $[\mathrm{M}]$ because the
Fig. 4 Calculated $E_{\mathrm{m}}\left(\mathrm{Mn}^{\mathrm{III} / \mathrm{IV}}\right)$ values of the $\mathrm{Mn}_{3}[\mathrm{M}] \mathrm{O}_{2}$ clusters (blue diamonds) and calculated $E_{\mathrm{m}}\left(\mathrm{Mn}^{\mathrm{III} / \mathrm{IV}}\right)$ values of the metalremoved $\mathrm{Mn}_{3} \mathrm{O}_{2}$ clusters (red circles) plotted with experimentally measured $E_{\mathrm{m}}\left(\mathrm{Mn}^{\mathrm{III} / \mathrm{IV}}\right)$ values in $\mathrm{CH}_{2} \mathrm{Cl}_{2}$ (Tsui and Agapie 2013)

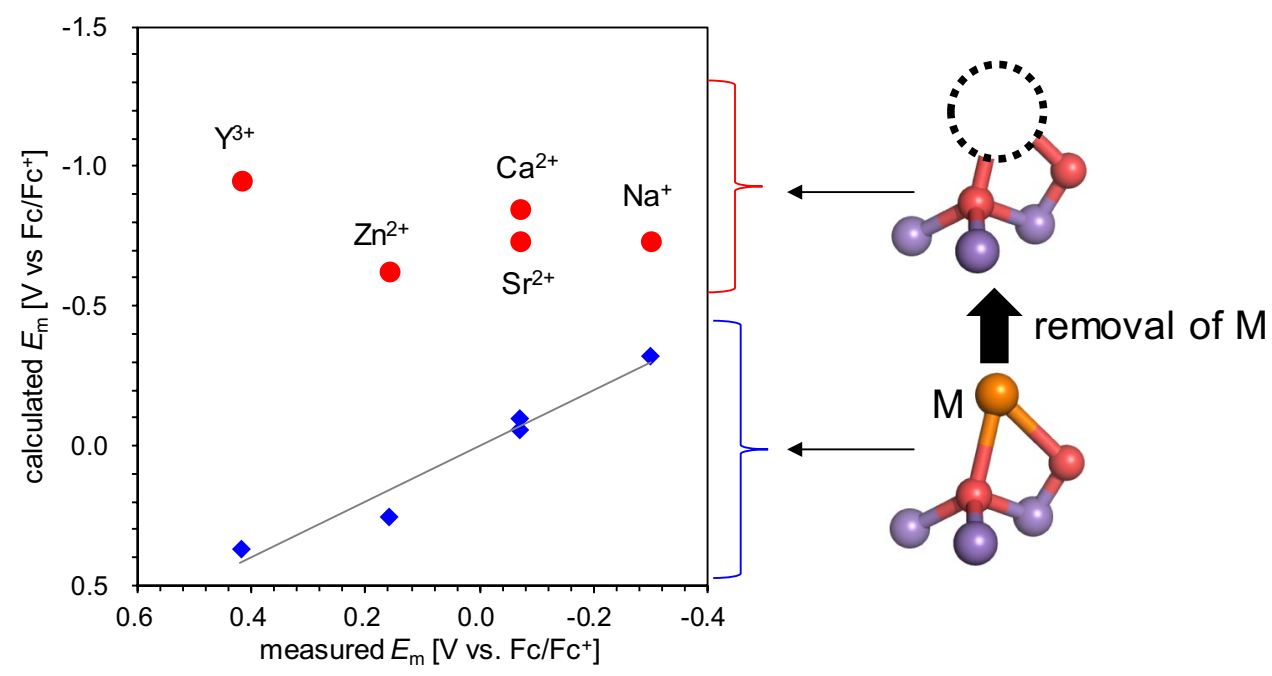


(a)

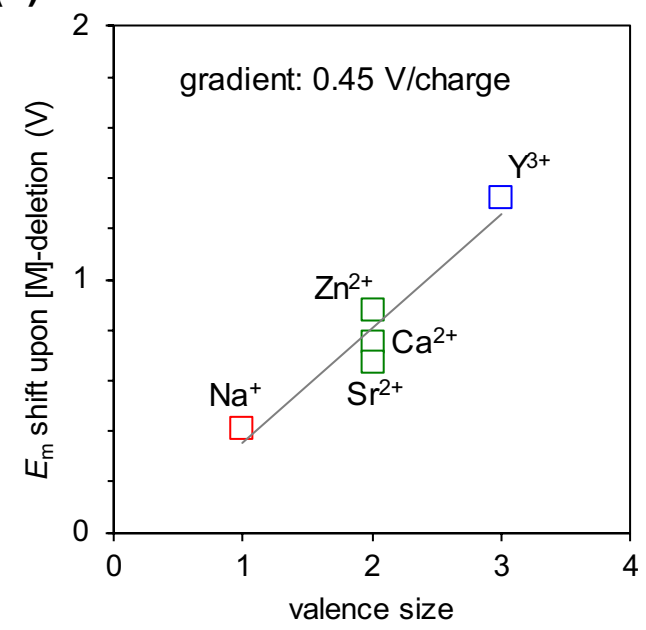

(b)

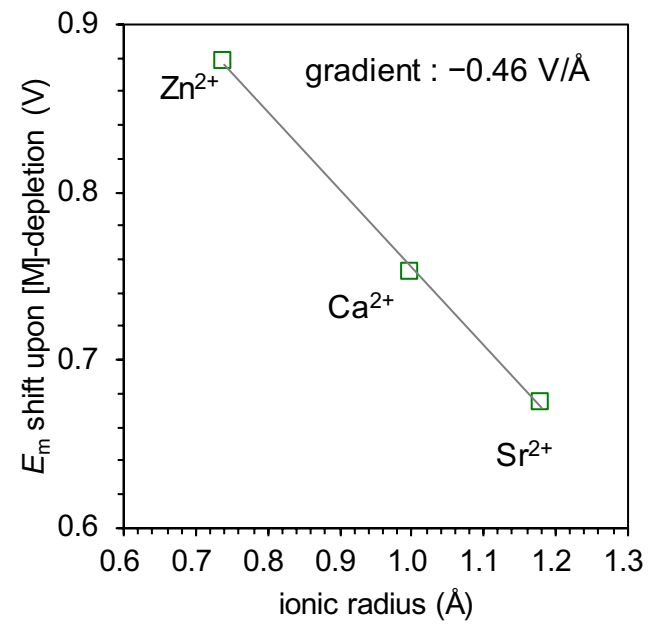

Fig. 5 Shift in $E_{\mathrm{m}}$ upon the removal of $[\mathrm{M}]\left([\mathrm{M}]=\mathrm{Na}^{+}(\right.$red $), \mathrm{Sr}^{2+}, \mathrm{Ca}^{2+}, \mathrm{Zn}^{2+}$ (green), and $\mathrm{Y}^{3+}$ (blue) $)$ a with respect to the valence $\left(R^{2}=0.93\right)$ and $\mathbf{b}$ with respect to the ionic radius (Shannon 1976) of $[\mathrm{M}]\left([\mathrm{M}]=\mathrm{Sr}^{2+}, \mathrm{Ca}^{2+}\right.$, and $\left.\mathrm{Zn}^{2+}\right)\left(R^{2}=0.99\right)$

Lewis acidity decreases with an increase in the ionic radius (Lin et al. 2015).

In PSII, $E_{\mathrm{m}}\left(\mathrm{Mn} 1^{\mathrm{III} / \mathrm{IV}}\right)$ of the $\mathrm{Mn}_{4} \mathrm{CaO}_{5}$ cluster changes by only $\sim 40 \mathrm{mV}$ even upon the replacement ion of $\mathrm{Ca}^{2+}$ with $\mathrm{H}_{3} \mathrm{O}^{+}$irrespective of the loss of a +1 charge (Saito et al. 2020a). In contrast, $E_{\mathrm{m}}\left(\mathrm{Mn}^{\mathrm{III} / \mathrm{IV}}\right)$ of the $\mathrm{Mn}_{3}[\mathrm{M}] \mathrm{O}_{2}$ cluster changes by $450 \mathrm{mV}$ upon the loss of a +1 charge (Fig. 5a). These indicate that the protein environment including the H-bond network (e.g., D1-Asp61, TyrZ, D1-His 190, and water molecules) plays a key role in determining the $E_{\mathrm{m}}\left(\mathrm{Mn}_{4} \mathrm{CaO}_{5}\right)$ in PSII.

In summary, the quantum-chemically calculated HOMO energies of artificial $\mathrm{Mn}_{3}[\mathrm{M}] \mathrm{O}_{2}$ clusters $\left([\mathrm{M}]=\mathrm{Na}^{+}, \mathrm{Sr}^{2+}\right.$, $\mathrm{Ca}^{2+}, \mathrm{Zn}^{2+}$, and $\mathrm{Y}^{3+}$ ) correlate with the experimentally measured $E_{\mathrm{m}}\left(\mathrm{Mn}^{\mathrm{III} / \mathrm{IV}}\right)$ values (Fig. 3 ). The $E_{\mathrm{m}}$ calculation for the metal-deleted $\mathrm{Mn}_{3} \mathrm{O}_{2}$ clusters shows that the valence of [M] predominantly affects $E_{\mathrm{m}}$ (Fig. 5a), whereas the ionic radius of [M] affects $E_{\mathrm{m}}$ only slightly (Fig. 5b).

Supplementary Information The online version contains supplementary material available at https://doi.org/10.1007/s11120-021-00846-y.

Funding This study was supported by JST CREST (JPMJCR1656 to H.I.), JSPS KAKENHI (18H05155, 18H01937, 20H03217, and $20 \mathrm{H} 05090$ to H.I.; $18 \mathrm{H} 01186$ to K.S.; and $16 \mathrm{H} 06560$ to K.S.), and the Interdisciplinary Computational Science Program in CCS, University of Tsukuba (K.S.).

\section{Declarations}

Conflict of interest The authors declare that they have no conflict of interest.

Open Access This article is licensed under a Creative Commons Attribution 4.0 International License, which permits use, sharing, adaptation, distribution and reproduction in any medium or format, as long as you give appropriate credit to the original author(s) and the source, provide a link to the Creative Commons licence, and indicate if changes were made. The images or other third party material in this article are included in the article's Creative Commons licence, unless indicated otherwise in a credit line to the material. If material is not included in the article's Creative Commons licence and your intended use is not permitted by statutory regulation or exceeds the permitted use, you will need to obtain permission directly from the copyright holder. To view a copy of this licence, visit http://creativecommons. org/licenses/by/4.0/.

\section{References}

Ames W, Pantazis DA, Krewald V, Cox N, Messinger J, Lubitz W, Neese F (2011) Theoretical evaluation of structural models of the $\mathrm{S}_{2}$ state in the oxygen evolving complex of photosystem II: protonation states and magnetic interactions. J Am Chem Soc 133(49):19743-19757. https://doi.org/10.1021/ja2041805

Amin M, Vogt L, Vassiliev S, Rivalta I, Sultan MM, Bruce D, Brudvig GW, Batista VS, Gunner MR (2013) Electrostatic effects on proton coupled electron transfer in oxomanganese complexes inspired by the oxygen-evolving complex of photosystem II. J Phys Chem B 117(20):6217-6226. https://doi.org/10.1021/jp403321b

Bang S, Lee YM, Hong S, Cho KB, Nishida Y, Seo MS, Sarangi R, Fukuzumi S, Nam W (2014) Redox-inactive metal ions modulate the reactivity and oxygen release of mononuclear non-haem iron(III)-peroxo complexes. Nat Chem 6(10):934-940. https://doi. org/10.1038/nchem.2055

Cardona T, Rutherford AW (2019) Evolution of photochemical reaction centres: more twists? Trends Plant Sci 24(11):1008-1021. https:// doi.org/10.1016/j.tplants.2019.06.016

Conradie J (2015) A Frontier orbital energy approach to redox potentials. J Phys Conf Ser 633:012045. https://doi.org/10.1088/17426596/633/1/012045

Dance I (2006) The correlation of redox potential, HOMO energy, and oxidation state in metal sulfide clusters and its application to determine the redox level of the FeMo-co active-site cluster of nitrogenase. Inorg Chem 45(13):5084-5091 
Igarashi RY, Seefeldt LC (2003) Nitrogen fixation: the mechanism of the Mo-dependent nitrogenase. Crit Rev Biochem Mol Biol 38(4):351-384

Ishikita H, Saito K (2020) Redox potentials of quinones in aqueous solution: relevance to redox potentials in protein environments. In: Wang Q (ed) Microbial photosynthesis. Springer, Singapore, pp 115-120

Isobe H, Shoji M, Yamanaka S, Umena Y, Kawakami K, Kamiya N, Shen JR, Yamaguchi K (2012) Theoretical illumination of waterinserted structures of the $\mathrm{CaMn}_{4} \mathrm{O}_{5}$ cluster in the $\mathrm{S}_{2}$ and $\mathrm{S}_{3}$ states of oxygen-evolving complex of photosystem II: full geometry optimizations by B3LYP hybrid density functional. Dalton Trans 41(44):13727-13740

Kanady JS, Mendoza-Cortes JL, Tsui EY, Nielsen RJ, Goddard WA, Agapie T (2013) Oxygen atom transfer and oxidative water incorporation in cuboidal $\mathrm{Mn}_{3} \mathrm{MO}_{\mathrm{n}}$, complexes based on synthetic, isotopic labeling, and computational studies. J Am Chem Soc 135(3):1073-1082

Kawakami K, Umena Y, Kamiya N, Shen J-R (2011) Structure of the catalytic, inorganic core of oxygen-evolving photosystem II at $1.9 \AA$ resolution. J Photochem Photobiol B 104(1-2):9-18

Kawashima K, Saito K, Ishikita H (2018a) Mechanism of radical formation in the H-bond network of D1-Asn298 in photosystem II. Biochemistry 57(33):4997-5004. https://doi.org/10.1021/acs. biochem. 8 b00574

Kawashima K, Takaoka T, Kimura H, Saito K, Ishikita H (2018b) $\mathrm{O}_{2}$ evolution and recovery of the water-oxidizing enzyme. Nat Commun 9:1247-1257

Kishi S, Saito K, Kato Y, Ishikita H (2017) Redox potentials of ubiquinone, menaquinone, phylloquinone, and plastoquinone in aqueous solution. Photosynth Res 134(2):193-200. https:// doi.org/10.1007/s11120-017-0433-4

Koua FHM, Umena Y, Kawakami K, Shen JR (2013) Structure of Sr-substituted photosystem II at $2.1 \AA$ resolution and its implications in the mechanism of water oxidation. Proc Natl Acad Sci USA 110(10):3889-3894

Krewald V, Neese F, Pantazis DA (2016) Redox potential tuning by redox-inactive cations in nature's water oxidizing catalyst and synthetic analogues. Phys Chem Chem Phys 18(16):10739_ 10750. https://doi.org/10.1039/c5cp07213a

Latimer MJ, DeRose VJ, Yachandra VK, Sauer K, Klein MP (1998) Structural effects of calcium depletion on the manganese cluster of photosystem II: determination by X-ray absorption spectroscopy. J Phys Chem B 102:8257-8265

Lee CI, Lakshmi KV, Brudvig GW (2007) Probing the functional role of $\mathrm{Ca}^{2+}$ in the oxygen-evolving complex of photosystem II by metal ion inhibition. Biochemistry 46(11):3211-3223. https://doi.org/10.1021/bi062033i

Lin PH, Takase MK, Agapie T (2015) Investigations of the effect of the non-manganese metal in heterometallic-oxido cluster models of the oxygen evolving complex of photosystem II: lanthanides as substitutes for calcium. Inorg Chem 54(1):59-64

Lohmiller T, Cox N, Su JH, Messinger J, Lubitz W (2012) The basic properties of the electronic structure of the oxygen-evolving complex of photosystem II are not perturbed by $\mathrm{Ca}^{2+}$ removal. J Biol Chem 287(29):24721-24733

Mandal M, Kawashima K, Saito K, Ishikita H (2020) Redox potential of the oxygen-evolving complex in the electron transfer cascade of photosystem II. J Chem Phys Lett 11(1):249-255

Marenich AV, Ho J, Coote ML, Cramer CJ, Truhlar DG (2014) Computational electrochemistry: prediction of liquid-phase reduction potentials. Phys Chem Chem Phys 16(29):15068-15106. https://doi.org/10.1039/c4cp01572j

McEvoy JP, Brudvig GW (2006) Water-splitting chemistry of photosystem II. Chem Rev 106(11):4455-4483
Mendez-Hernandez DD, Tarakeshwar P, Gust D, Moore TA, Moore AL, Mujica V (2013) Simple and accurate correlation of experimental redox potentials and DFT-calculated HOMO/LUMO energies of polycyclic aromatic hydrocarbons. J Mol Model 19(7):2845-2848

Mukherjee S, Stull JA, Yano J, Stamatatos TC, Pringouri K, Stich TA, Abboud KA, Britt RD, Yachandra VK, Christou G (2012) Synthetic model of the asymmetric $\left[\mathrm{Mn}_{3} \mathrm{CaO}_{4}\right]$ cubane core of the oxygen-evolving complex of photosystem II. Proc Natl Acad Sci USA 109(7):2257-2262

Ono T, Inoue Y (1988) Discrete extraction of the Ca atom functional for $\mathrm{O}_{2}$ evolution in higher plant photosystem II by a simple low $\mathrm{pH}$ treatment. FEBS Lett 227(2):147-152

Ono T, Rompel A, Mino H, Chiba N (2001) Ca2+ function in photosynthetic oxygen evolution studied by alkali metal cations substitution. Biophys J 81(4):1831-1840

Pitari F, Bovi D, Narzi D, Guidoni L (2015) Characterization of the $\mathrm{Sr}^{2+}$ - and $\mathrm{Cd}^{2+}$-substituted oxygen-evolving complex of photosystem II by quantum mechanics/molecular mechanics calculations. Biochemistry 54(38):5959-5968. https://doi.org/10.1021/ acs.biochem. 5 b00797

Saito K, Ishikita H (2014) Influence of the $\mathrm{Ca} 2+$ ion on the $\mathrm{Mn} 4 \mathrm{Ca}$ conformation and the $\mathrm{H}$-bond network arrangement in photosystem II. Biochim Biophys Acta 1837(1):159-166

Saito K, Shen J-R, Ishida T, Ishikita H (2011) Short hydrogen-bond between redox-active tyrosine $\mathrm{Y}_{\mathrm{Z}}$ and D1-His190 in the photosystem II crystal structure. Biochemistry 50:9836-9844

Saito K, Mandal M, Ishikita H (2020a) Energetics of ionized water molecules in the H-bond network near the $\mathrm{Ca}^{2+}$ and $\mathrm{Cl}^{-}$binding sites in photosystem II. Biochemistry 59(35):3216-3224. https:// doi.org/10.1021/acs.biochem.0c00177

Saito K, Mandal M, Ishikita H (2020b) Redox potentials along the redox-active low-barrier H-bonds in electron transfer pathways. Phys Chem Chem Phys. https://doi.org/10.1039/d0cp04265j

Saito K, Nakagawa M, Ishikita $\mathrm{H}$ (2020c) $\mathrm{p} K_{\mathrm{a}}$ of the ligand water molecules in the oxygen-evolving $\mathrm{Mn}_{4} \mathrm{CaO}_{5}$ cluster in photosystem II. Commun Chem 3(1):89. https://doi.org/10.1038/ s42004-020-00336-7

Schmidt am Busch M, Knapp E-W (2005) One-electron reduction potential for oxygen- and sulfur-centered organic radicals in protic and aprotic solvents. J Am Chem Soc 127:15730-15737

Shannon RD (1976) Revised effective ionic-radii and systematic studies of interatomic distances in halides and chalcogenides. Acta Crystallogr Sect A Cryst Phys Diffr Theor Gen Crystallogr 32:751-767

Shen JR (2015) The structure of photosystem II and the mechanism of water oxidation in photosynthesis. Annu Rev Plant Biol 66:23-48. https://doi.org/10.1146/annurev-arplant-050312-120129

Siegbahn PEM (2014) Water oxidation energy diagrams for photosystem II for different protonation states, and the effect of removing calcium. Phys Chem Chem Phys 16(24):11893-11900. https://doi. org/10.1039/c3cp55329a

Siegbahn PE (2017) Water oxidation by PSII-a quantum chemical approach. In: Wikström M (ed) Mechanisms of primary energy transduction in biology. The Royal Society of Chemistry, London, pp 273-295

Tsui EY, Agapie T (2013) Reduction potentials of heterometallic manganese-oxido cubane complexes modulated by redox-inactive metals. Proc Natl Acad Sci USA 110(25):10084-10088

Tsui EY, Tran R, Yano J, Agapie T (2013) Redox-inactive metals modulate the reduction potential in heterometallic manganese-oxido clusters. Nat Chem 5(4):293-299

Umena Y, Kawakami K, Shen J-R, Kamiya N (2011) Crystal structure of oxygen-evolving photosystem II at a resolution of $1.9 \AA$. Nature 473(7345):55-65. https://doi.org/10.1038/nature09913 
Vacek G, Perry JK, Langlois JM (1999) Advanced initial-guess algorithm for self-consistent-field calculations on organometallic systems. Chem Phys Lett 310:189-194

Yachandra VK, Yano J (2011) Calcium in the oxygen-evolving complex: structural and mechanistic role determined by X-ray spectroscopy. J Photochem Photobiol B 104(1-2):51-59

Yamaguchi K, Yamanaka S, Isobe H, Saito T, Kanda K, Umena Y, Kawakami K, Shen J-R, Kamiya N, Okumura M, Nakamura H, Shoji M, Yoshioka Y (2013) The nature of chemical bonds of the $\mathrm{CaMn}_{4} \mathrm{O}_{5}$ cluster in oxygen evolving complex of photosystem II: Jahn-Teller distortion and its suppression by Ca doping in cubane structures. Int J Quantum Chem 113:453-473

Zhang G, Musgrave CB (2007) Comparison of DFT methods for molecular orbital eigenvalue calculations. J Phys Chem A 111(8):1554-1561. https://doi.org/10.1021/jp061633o
Zhang CX, Chen CH, Dong HX, Shen JR, Dau H, Zhao JQ (2015) A synthetic Mn4Ca-cluster mimicking the oxygen-evolving center of photosynthesis. Science 348(6235):690-693

Zimmermann JL, Rutherford AW (1986) Electron paramagnetic resonance properties of the $\mathrm{S} 2$ state of the oxygen-evolving complex of photosystem II. Biochemistry 25(16):4609-4615. https://doi. org/10.1021/bi00364a023

Publisher's Note Springer Nature remains neutral with regard to jurisdictional claims in published maps and institutional affiliations. 